\title{
Exu e a ordem do universo
}

Resenha: SÀLÁMì, Síkírù (King); RIBEIRO, Ronilda lakemi. Exu e a ordem do universo. 2. Ed. São Paulo: Oduduwa, 2015. 483 p.

\author{
Rodrigo Ribeiro Frias \\ Universidade de São Paulo (USP) \\ rodrigoribeirofrias@usp.br
}

DOI: https://doi.org/10.22481/odeere.v3i3.1579

Saudação a Exu

Terra, cujo poder se espalha por todo o universo, eu te saúdo!

É sobre você que se caminha primeiro,

Antes de se entrar na água.

Exu Odara, eu te saúdo!

Eu saúdo a madrugada!

Saúdo o Sol nascente!

Saúdo o sol poente!

Saúdo os primórdios da existência!

Saúdo os criadores da existência!

Eles são os veneráveis do universo.

Eu saúdo Exu, que deve ser louvado

Antes dos demais orixás.

Em pé, eu saúdo Exu.

Agachado, eu saúdo Exu.

Prostrado no chão, eu saúdo Exu.

Eu saúdo a força vital masculina!

Saúdo a força vital feminina!

Saúdo a força vital das crianças!

Saúdo a força vital dos anciãos sábios!

Saúdo a todos vocês antes de iniciar o awô!

Venho especialmente saudar você, Exu,

O poderoso, Senhor do Axé, filho de Eledunmare. 
Esta saudação é para você, Elegbara!

Oh! Esta saudação é para você, Exu! SÀLÁMì, S. (King); RIBEIRO, R. I. Exu e a ordem do universo. 2. Ed. São Paulo: Oduduwa, 2015, p. 361.

Com este excerto de uma saudação a Exu dou início à resenha de uma obra querida, dessas que valem por uma vida. Exu e a ordem do universo reúne informações abrangentes e fidedignas a respeito do orixá primordial Exu, tal como é cultuado em várias regiões do território iorubá. O Babalorixá Síkírù Sàlámì (Babá King), doutor em Sociologia, e a lalorixá Ronilda Iyakemi Ribeiro, doutora em Psicologia e em Antropologia, dedicaram cerca de vinte anos para concluir a obra, incluindo uma vasta pesquisa de campo conduzida por Sàlámì junto a informantes tradicionalistas da palavra. A segunda edição conta com dois prefácios, introdução, um corpo principal, um glossário notável e uma ampla seção de referências.

O corpo principal do livro é constituído de três partes. A primeira, Os iorubás: o humano, o divino e o código ético-moral, reúne três capítulos: (1) Noção iorubá de pessoa e práticas mágico-medicinais; (2) O divino na tradição de orixás. Teologia iorubá: Eledunmare, Orixás e Ancestrais e (3) Valores e virtudes: o código ético-moral iorubá. As noções de pessoa, tempo e universo favorecem o entendimento do contexto originário do Orixá Exu, enquanto as de saúde, doença e cura alicerçam a compreensão de práticas ritualísticas e mágico-medicinais. Nesse capítulo ganham destaque os poderes naturais e os ancestrais veneráveis; são apresentadas algumas das divindades mais cultuadas pelos iorubás: Ogum, Xangô, Oxóssi, Logunedé, lemanjá, Oxum, Oyá, Iyami Oxorongá, Egungun, Geledés e Egbé Aragbo, entre outras. Evidencia-se, ainda, que Eledunmare, o Ser Supremo, ocupa a principal posição nesse sistema teológico. Mostra-se, enfim, que entre os iorubás um ser humano completo e íntegro cultiva virtudes - como paciência, justiça, organização, disciplina e compaixão - e luta por valores - como longevidade (saúde, vida longa), fertilidade (prole numerosa) e prosperidade (trabalho honesto e renda digna).

A segunda parte da obra, Exu: aspectos teológicos e litúrgicos, reúne os capítulos (4) Natureza e ação de Exu; (5) Exu e destino humano; (6) A dinâmica estabelecida entre orí e ìwà e a ação de Exu; (7) Símbolos, rituais e oferendas e (8) (In)Compreensão de Exu no continente de origem e em países da diáspora. Nessa parte são expostos de forma didática algumas das características mais relevantes de Exu, seus símbolos, rituais realizados em sua homenagem e 
alguns dos diversos modos de cultuá-lo. Contrariando as crenças de ser Exu um ser maligno ou um ser que oscila entre o bem e o mal, Sàlámì e Ribeiro enfatizam suas qualidades de orixá bondoso, paciente, justo, correto, mantenedor da ordem, da disciplina e da organização, que aprecia servir a todos os seres - lembrando que, entre os iorubás, servir a pessoas e a coletivos não constitui condição degradante e sim ato nobre, comportamento fundamentado em virtudes capitais. Os autores afirmam que Exu apoia os seus devotos de bom caráter e bom comportamento para que possam evitar a ação de inclinações pessoais negativas, ocorrências negativas determinadas pela predestinação e males advindos do meio. Os apoia, ainda, em seus esforços por atrair e preservar o que há de positivo em si próprios e em seu entorno. Nessa parte da obra há recomendações relativas ao uso de indumentárias, colares, pulseiras e outros símbolos de Exu e ao adequado preparo e entrega de oferendas. Sendo Exu amante da ordem, da disciplina, da organização, da paciência e de muitas outras virtudes, o leitor é estimulado a cultuá-lo por meio do exercício contínuo dessas virtudes, o que desenvolve aspectos positivos da personalidade e do caráter.

A terceira parte do livro, Presença de Exu no corpus da tradição oral iorubá, reúne os capítulos (9) Transmissão oral de conhecimentos. Corpus literário e sistema divinatório de Ifá; (10) Mitos de Exu nos odus de Ifá (iorubá); (11) Mitos de Exu nos odus de Ifá (português); (12) Oríkì, àdúrà e ibà Èsù: evocações, rezas e saudações a Exu; e (13) Orin Èsù: Cantigas de Exu. O registro e o tratamento respeitoso de informações orais, obtidas junto a tradicionalistas iorubás da Nigéria no decorrer de muitos anos, faz desta obra uma contribuição única. Preservam-se e veiculam-se saberes ancestrais e apreende-se características de Exu e maneiras de cultuá-lo, incluindo a recitação correta do corpo litúrgico a ele dedicado. É fato sabido que em sociedades negroafricanas a palavra é o grande agente da magia e da medicina. Por isso o entoar rezas, cantigas e saudações aos orixás, compreendendo seu conteúdo, específico para cada ritual, inclui-se entre as chaves para a pretendida veiculação do axé. Acrescenta-se a isso o fato de que as informações coletadas nesse território de origem desvelam traços da complexa civilização iorubá, entre os quais a fineza de espírito e a extraordinária potência intelectual desse grupo étnico africano.

A leitura dessa obra esclarece que a evocação de atributos específicos de Exu é realizada por meio da evocação de seus nomes. Sàlámì e Ribeiro registram vários desses nomes: Atèlé Elédàá, indicador de que Exu acompanha o ser humano e protege seu Ori, favorecendo sua sorte, 
prosperidade e felicidade; Elégbèjé Àdó, indicador de que Exu domina conhecimentos sobre òògùn, a arte mágico-medicinal iorubá, e possui poderes de cura e de eliminação de sofrimentos; Elégbárá evoca em Exu suas qualidades de sabedoria, acolhimento e poder: por meio dessa evocação ele é solicitado a defender o seu devoto e a atribuir-lhe poder para obtenção do sucesso pretendido; Ìràwò̀-Àkódá remete o evento mítico de haver sido Exu a primeira criação de Eledunmare, tendo sido de sua responsabilidade a organização do caos que precedeu a criação e foi o primórdio e o alicerce de tudo (este atributo é especialmente expressivo na sociedade iorubá dado ser o princípio da senioridade um dos elementos estruturantes da hierarquia social desse grupo étnico, para o qual a liderança deve ser confiada aos mais velhos; como a palavra ìwà designa caráter, personalidade e comportamento, evoca-se Exu por esse nome - Ìwá - para que apoie as pessoas em seis esforços pelo aprimoramento das próprias virtudes; a evocação Láaróyè realça o poder de comunicação de Exu;. Látoópa, sua inclinação para manter a ordem, a disciplina e a obediência a princípios; Olówó Òrìsà, sua habilidade para atrair fortuna e prosperidade; Onílèoríta, seu posto de guardião das encruzilhadas, incluindo encruzilhadas de encontro entre os mundos visível e invisível, de casas, cidades e demais espaços; Òrìsà-olomo ${ }_{2}$ seu poder de gerar e proteger crianças e devotos. Oba Sùúrú, sua qualidade de rei da paciência; Òdàrà, sua benevolência, bondade, beleza. Cada forma utilizada para evoca-lo desvela uma de suas qualidades e a promove em seus devotos.

Evidencia-se na obra que Exu, mensageiro dos orixás, responsável pela condução do ebó a seu destino, comunicador por excelência, promove encontros extremamente ricos entre os seres. Exu é também o inspetor dos rituais, o grande fiscal da ordem das coisas, o patrono da ordem, da disciplina e da organização, o grande apreciador das virtudes - paciência, honestidade, polidez, lealdade, respeito, coragem, perseverança - e o grande apreciador de valores longevidade, fecundidade, prosperidade, verdade, compromisso com o coletivo. A devoção a esse Orixá implica o desenvolvimento dessas e de outras qualidades humanas.

Todos os iniciados em Exu são seus representantes, seus "assentamentos simbólicos", tendo a responsabilidade de adotar uma postura nobre, condizente com o fato de serem portadores de seu axé. Como os demais orixás, Exu zelam pela Ética e favorece o aprimoramento humano. Não compete a ele solucionar problemas ou eliminar dificuldades de seus devotos. No 
entanto, seu apoio é fundamental, pois o fluir de seu axé favorece a compreensão de que as conquistas pessoais e sociais dependem primeiramente de esforços pessoais e de conduta solidária.

Diz uma cantiga desse Orixá: Exu, que pode apoiar, Exu, que pode alterar iwá, Que pode melhorar iwá, faça isso por mim! Que Exu nos ajude a aprimorar nosso caráter e nos torne dignos de cultuá-lo! Eis uma das principais mensagens da obra aqui resenhada.

Rodrigo Ribeiro Frias: Possui graduação em Letras-Português pela Faculdade de Filosofia, Letras e Ciências Humanas da USP (2000) e Mestrado em Teoria Literária pela mesma instituição (2005). Atualmente cursa o Doutorado em Psicologia Social pelo Instituto de Psicologia da USP. Em sua experiência em Letras a ênfase recai sobre Literatura, particularmente nos seguintes temas: Carlos Drummond de Andrade; poesia lírica moderna e contemporânea; teoria e crítica literárias; mitologia e tradição oral. Em sua atuação como pesquisador atua na área de confluência da Literatura com a Antropologia, a Psicologia e a Educação. Nessa confluência o foco de seus interesses recai sobre o potencial educacional de narrativas mitológicas e outras formas literárias da tradição oral; recai também sobre os conceitos de identidade religiosa e comunidade. Nos últimos anos vem se dedicando a estudos e pesquisas sobre a etnia iorubá (África Ocidental), especialmente sobre o Corpus Literário de Ifá, corpo da tradição oral desse grupo étnico, de marcante presença no Brasil.

Resenha recebida para publicação em: Maio de 2017.

Resenha aprovada para publicação em: Junho de 2017. 